Jurnal

Manajemen Kesehatan Indonesia

Volume 5

Nomor 2

Agustus 2017

\title{
Analisis Faktor -Faktor yang Mempengaruhi Pemahaman Pasien terhadap Informed Consent di Rumah Sakit
}

\author{
Dewangga Primananda Susanto*, Bramantya Surya Pratama ${ }^{* *}$, Tuti Hariyanto** \\ "Mahasiswa Program Studi Magister Manajemen Rumah Sakit Fakultas Kedokteran Universitas \\ Brawijaya \\ ** Staff Pengajar Fakultas Kedokteran Universitas Brawijaya \\ email:dewangga.primananda@yahoo.com
}

\section{ABSTRACT}

The effect of patient safety in good hospitals are illustrated by a good informed consent process in accordance with applicable regulations. Not a few hospitals lost the process of good informed consent, so caught up in the legal process during the incident. This study aims to determine, analyze and examine the factors that affect the understanding of patient informed consent in RSU X. This research uses explorative research with descriptive approach. The respondents of this study were divided into two groups: in-patients and medical teams between nurses and doctors at Hospital X. This study found the root causes of informed consent in patient unresponsiveness after a questionnaire analysis and focus group discussion (FGD) at RSU X. The result is 1) There is no method / tool to facilitate health personnel in explaining, (2) No media from the hospital to facilitate, (3) No appointment of person in charge, (4) Awareness of informed consent does not exist, and (5) Lack of socialization of Standard Operational Procedure and no policies. The solution is the creation of a media to assist in improving the understanding of patient informed consent such as building model like photonovela.

Keywords: Medical Information; Approval of Medical Action; Understanding Informed Consent

\section{PENDAHULUAN}

Patient safety merupakan salah satu indikator baik atau buruknya rumah sakit. Sebagai salah satu indikator rumah sakit yang memiliki patient safety yang baik adalah proses informed consent yang baik. Berbagai sengketa medik banyak terjadi di indonesia diakibatkan proses informed consent yang kurang baik dimulai dari adanya tuntutan hukum di bidang kesehatan yang menjadi perhatian utama praktisi kesehatan di Indonesia, salah satunya adalah dengan banyaknya kasus dokter yang diduga melakukan kasus malpraktik dan heboh beberapa waktu lalu. Berbagai usaha oleh pihak berwenang telah dilakukan untuk mengatur informed consent yaitu Peraturan Menteri Kesehatan Nomor 290 tahun 2008. Di era akreditasi KARS versi 2012, patient safety dan tindakan informed consent yang baik merupakan syarat kelulusan akreditasi rumah sakit ${ }^{1}$. 
Rumah sakit X merupakan rumah sakit yang telah terakreditasi tingkat dasar sejak mei 2016. Seharusnya status akreditasi yang dimiliki sejalan dengan proses informed consent yang baik dan benar. Berdasarkan studi pendahuluan yang dilakukan di RSU X melalui wawancara terdapat beberapa laporan kasus insiden yang terjadi di Instalasi Gawat Darurat (IGD) pada bulan JuliAgustus yang menimbulkan kritikan, komplain dan tuntutan hukum dari pasien dan rumah sakit rujukan. Setelah dilakukan analisa, akar masalah pada studi pendahuluan, kejadian tersebut terjadi karena pelaksanaan komunikasi terhadap informed consent yang kurang baik di RS $\mathrm{X}$.

Pemberian informed consent merupakan suatu jembatan antara dokter dan pasien yang merupakan proses komunikasi dalam menentukan pengobatan dan terapi terbaik kepada pasien. Informed consent harus dijelaskan secara lengkap pada pasien tentang diagnosa, Jenis tindakan, tata cara, tujuan, alternatif, resiko dan komplikasi tindakan, prognosis, dan perkiraan pembayaran. ${ }^{2}$ Selain itu, penjelasan proses pencatatan dan permintaan tanda tangan sebagai persetujuan diperlukan sebagai syarat pelaksanaan informed consent yang baik. ${ }^{3}$ Penelitian ini dilakukan untuk mencari penyebab utama dan faktor-faktor tidak efektifnya penerapan penyampaian informasi medis dan menilai seberapa besar ketidakpahaman pasien terhadap informed consent sebagai pertimbangan dan persetujuan medis serta menggali alternatif solusi dan implementasinya bagi rumah sakit.

\section{METODE PENELITIAN}

Penelitian ini dilakukan dengan tahapan pengumpulan data, studi literatur, dan brainstorming. Pengumpulan data dengan metode kuesioner yang diberikan secara berbeda kepada pasien dan tenaga medis yang memberikan informasi informed consent. Proses pengamatan dilakukan melalui 4 indikator pada pasien dan 3 indikator pada tenaga medis. Indikator tersebut adalah pra pemberian informed consent, saat pemberian informed consent, paska pemberian informed consent untuk pasien dan tenaga medis. Kriteria inklusi yang dipilih adalah informed consent pada tindakan rawat inap berupa pemasangan infus, Naso Gastric Tube (NGT) dan kateter urin, hari perawatan yang diambil adalah semua pasien yang masih menjalani rawat inap di RSU X dalam kurun 1 hingga 3 hari, dan seluruh sampel yang diambil merupakan pasien atau pengantar pasien yang diberikan informed consent oleh dokter atau perawat secara langsung selama di IGD maupun di rawat inap.

Studi literatur dilakukan untuk mengetahui kelengkapan informed consent yaitu formulir informed consent pada rekam medis pasien yang menjadi responden di ruang rawat inap RSU X dan SOP (Standard Operational Procedure) informed consent yang terkait. Proses pengumpulan data dan studi dokumen dilakukan selama 2 minggu dengan jumlah sampel yang diambil berjumlah 75 orang dan dipilih secara purposive sampling dengan rincian 50 orang sampel pada seluruh pasien baru yang masuk dan 25 orang tenaga medis (perawat dan dokter). Brainstorming dilakukan untuk mencari akar penyebab masalah dan alternatif solusi, dengan jumlah peserta sebanyak 20 orang yang terdiri dari kepala setiap 
ruangan dan seluruh tim managemen, dilanjutkan dengan tehnik Fishbone Ishikawa dan "5 Whys", pemilihan alternatif solusi dengan metode Mc.Namara, dimana dari empat alternatif solusi yang ada kemudian di lakukan skoring, sehingga skor tertinggi adalah solusi yang terpilih untuk di implementasikan di RSU X ${ }^{4}$.

\section{HASIL}

Berdasarkan observasi di unit-unit RS Umum $\mathrm{X}$ menunjukkan bahwa tindakan medis di RSU X yang dijadikan proses penelitian dikelompokkan menjadi informed consent yang dilengkapi dengan form, yaitu tindakan infus pemasangan. Infus lebih sering didapatkan karena hampir semua pasien di UGD dan Rawat Inap dilakukan tindakan tersebut.

\section{INDIKATOR KEMAMPUAN PASIEN}

Indikator kemampuan pasien merupakan penilaian kemampuan pasien terhadap kebutuhan bantuan penjelasan lebih oleh tenaga medis terkait penjelasan informed consent berdasarkan health literacy atau kemampuan pasien dalam memahami penjelasan medis. Pertanyaan pada indikator health literacy didasarkan pada pertanyaan pada single item literacy screeners (SILS), schooling, opinion (Self rated reading ability/SRRA) dan reading enjoyment, support (S.O.S) mnemonic, dan beberapa list pertanyaan yang diusulkan oleh Canadian Public Health Association. 5

Kemampuan pasien dalam memahami penjelasan yang diberikan dapat dilihat berdasarkan hasil kuesioner yaitu $82 \%$ pasien memiliki kemampuan baca yang rendah, $56 \%$ pasien memiliki frekuensi baca yang jarang. Selain itu
$62 \%$ responden pasien meminta tolong orang lain dalam membaca hal- hal di Rumah Sakit dan 20\% tidak percaya diri dalam mengisi formulir di Rumah Sakit. Selain itu, sebanyak $62 \%$ pasien memiliki permasalahan mengenai kondisi medis/penyakit sehingga mengalami kesulitan pemahaman tentang kata-kata medis yang tertulis. Hal ini dapat disimpulkan bahwa kemampuan health literacy pasien rendah dan memerlukan bantuan penjelasan lebih terkait informasi medis yang diberikan, terutama mengenai penjelasan informed consent. ${ }^{6}$

\section{INDIKATOR PRA PEMBERIAN INFORMED CONSENT}

Indikator pra pemberian informed consent dibuat dengan tujuan mengetahui pemahaman pasien dan tenaga medis terkait arti, fungsi dan pentingnya informed consent,. Indikator ini menggambarkan kemampuan dasar pasien dalam memahami informed consent. Beberapa data yang didapat adalah responden yang berusia 40 tahun mencapai $60 \%$ dan $90 \%$ pasien diantaranya tidak mengetahui mengenai arti informed consent, sedangkan $84 \%$ pasien tidak mengetahui mengenai fungsi informed consent. Menurut $96 \%$ responden, informed consent dinyatakan penting. Selain melihat tingkat pemahaman pada pasien, diperhatikan pula faktor yang mempengaruhi informed consent. Sebanyak 98\% responden tenaga medis berusia kurang dari 30 tahun, dan $60 \%$ responden memiliki pengalaman di bawah 4 tahun, sedangkan $68 \%$ responden memiliki pengalaman kerja di RS X hanya 2 tahun.

Pada tingkat pendidikan, sebanyak $68 \%$ merupakan lulusan D3 dan keseluruhan menyebutkan bahwa informed 
consent penting, dan mereka sering melakukan informed consent. Sebanyak $36 \%$ responden menyebutkan bahwa mereka pernah melakukan pendelegasian dalam menjelaskan informed consent.

\section{INDIKATOR SAAT PEMBERIAN INFORMED CONSENT}

Indikator pemberian informed consent baik tenaga medis maupun pasien dinilai dari proses pelaksanaan infomed consent oleh tim medis dan elemen-elemen informed consent dengan cross check pada pasien berupa diagnosa, jenis tindakan, tata cara tindakan, tujuan tindakan, alternatif tindakan, risiko tindakan, komplikasi tindakan, prognosa tindakan, dan perkiraan pembiayaan sesuai dengan Peraturan Mentri Kesehatan (PMK) Nomor 269 tahun 2008 tentang Persetujuan Tindakan Medik ${ }^{7}$. Data yang diperoleh adalah sebanyak $38 \%$ pasien tidak diberikan penjelesan mengenai informed consent, selain itu $5 \%$ pasien diantaranya mengaku sulit mengerti bahasa yang digunakan tenaga medis dalam menjelaskan.

Untuk menilai kemampuan tenaga medis dalam melakukan pemberian informed consent, didapatkan data bahwa tenaga medis rata-rata dapat menjawab 5 dari 9 soal dengan nilai maksimal. Ratarata jumlah jawaban sebanyak 130 jawaban, sedangkan jika dicross-check dengan standar element informed consent maka hanya 91 jawaban benar yang merupakan $40 \%$ dari seharusnya total 225 jawaban benar.

Data lain juga menyebutkan bahwa $8 \%$ tenaga medis menyebutkan bahwa waktu penjelasan informed consent tidak cukup. Tabel 1. menampilkan data perbandingkan jawaban benar sesuai elemen informed consent oleh tenaga medis, dan menilai pemahaman pasien dengan melihat persentase benar jawaban pasien sesuai elemen informed consent yang dijelaskan oleh tenaga medis. Sehingga dapat disimpulkan bahwa penjelasan informed consent pada tenaga kesehatan belum baik dan tidak lengkap didukung dengan pemahaman pasien yang rendah dalam menangkap arti dan maksud penjelasan tindakan yang akan dilaksanakan

\begin{tabular}{|c|c|c|c|c|c|}
\hline \multicolumn{4}{|c|}{ PEROLEHAN JUMLAH BENAR TENAGA MEDIS } & \multicolumn{2}{|c|}{$\begin{array}{l}\text { PEROLEHAN JUMLAH BENAR } \\
\text { PEROLEHAN PASIEN }\end{array}$} \\
\hline NO & JENIS ELEMENT & JUMLAH & PRESENTASE & JUMLAH & PRESENTASE \\
\hline 1 & Resiko & 20 & $14 \%$ & 4 & $8 \%$ \\
\hline 2 & Jenis tindakan & 17 & $12 \%$ & 48 & $96 \%$ \\
\hline 3 & $\begin{array}{l}\text { Tata cara tindakan / } \\
\text { prosedur tindakan }\end{array}$ & 17 & $12 \%$ & 11 & $22 \%$ \\
\hline 4 & Tujuan & 16 & $12 \%$ & 25 & $50 \%$ \\
\hline 6 & Komplikasi & 6 & $4 \%$ & 1 & $2 \%$ \\
\hline 7 & $\begin{array}{c}\text { Menjelaskan } \\
\text { alternatif tindakan }\end{array}$ & 6 & $4 \%$ & 3 & $6 \%$ \\
\hline 10 & Prognosa & 4 & $3 \%$ & 4 & $8 \%$ \\
\hline 11 & Dasar diagnosis & 3 & $2 \%$ & 49 & $98 \%$ \\
\hline 12 & Biaya & 0 & $0 \%$ & 0 & $0 \%$ \\
\hline
\end{tabular}

Tabel 1. Data perbandingan jumlah benar penilaian elemen informed consent antara tenaga medis dan pasien 


\section{INDIKATOR SETELAH PEMBERIAN INFORMED CONSENT}

Indikator paska pemberian informed consent dibuat dengan maksud untuk mengetahui proses setelah pelaksanaan pemberian informed consent oleh tenaga medis melalui persepsi pasien dan tenaga medis yang memberikan informed consent.

Sebanyak $30 \%$ pasien mengaku tidak diberi kesempatan bertanya, 30\% pasien mengaku tidak diberi penjelasan pertanyaannya, $8 \%$ pasien mengaku tidak diberi waktu berfikir oleh tenaga medis dalam menentukan jawaban, $40 \%$ pasien mengaku tidak ditanyakan pemahamannya, $18 \%$ pasien mengaku tidak mengerti jika memiliki hak untuk menolak, serta 30\% pasien menilai kurang terhadap keseluruhan hasil evaluasi penjelasan informed consent. Dalam proses memberikan tanda tangan, $100 \%$ pasien menandatangani informed consent tetapi terdapat $20 \%$ proses tanda tangan dilaksanakan setelah tindakan.

Untuk penilaian indikator pasca pemberian informed consent pada tenaga medis, didapatkan data bahwa 100\% tenaga medis mengaku telah memberikan kesempatan bertanya kepada pasien menjelaskan, memberi waktu berfikir, menanyakan pemahaman, memberitahukan bahwa pasien memiliki hak menolak, dan meminta tanda tangan. Selain itu, sebanyak $8 \%$ tenaga medis memberikan nilai sangat kurang pada proses pemberian informed consent yang dilakukannya, dan masih terdapat $12 \%$ tenaga medis yang meminta tanda tangan setelah tindakan. Berdasarkan form informed consent yang ada di RSU X, memerlukan beberapa revisi yakni berupa penambahan perkiraan biaya selain itu menghilangkan indikasi tindakan dan dasar diagnosa pada form. Selain itu keterangan penjelasan tentang alternatif perlu ditambahkan sedangkan penjelasan mengenai diagnosa perlu dikaji ulang. Dapat disimpulkan bahwa pelaksanaan proses paska pemberian informed consent pada pasien masih ditemukan pasien yang merasa tidak dilakukan proses cross-check pemahaman pasien dan evaluasi yang rendah, berbeda dengan tenaga medis yang seluruhnya merasakan telah melakukan proses tersebut dengan baik. Hanya saja masih ditemukan proses permintaan tanda tangan yang dilakukan setelah proses tindakan.

Brainstorming dilakukan untuk mencari faktor potensial yang berpengaruh terhadap rendahnya penyampaian informasi tindakan medis oleh tenaga medis di RSU X dengan peserta 20 orang terdiri dari kepala unit dan tim dari management. Identifikasi akar masalah dengan menggunakan diagram fishbone berdasarkan pada man, machine, method, environment dari pengamatan, wawancara dan brainstorming disajikan pada Gambar 1.

\begin{tabular}{llr}
\hline No & \multicolumn{1}{c}{ Alternatif solusi } & Total \\
\hline $\mathbf{1}$ & $\begin{array}{l}\text { Mengadakan } \\
\text { komunikasi } \\
\text { menyampaikan } \\
\text { tindakan medis }\end{array}$ & $\begin{array}{r}\text { cara } \\
\text { canformasi }\end{array}$ \\
$\mathbf{2}$ & $\begin{array}{l}\text { Pembuatan } \\
\text { pedoman pemberian informed } \\
\text { consent dengan pembuatan } \\
\text { poster/photonovela terkait } \\
\text { penjelasan informasi medis } \\
\text { untuk edukasi pasien }\end{array}$ \\
$\mathbf{3}$ & $\begin{array}{l}\text { Melaksanakan } \\
\text { monitoring dan evaluasi } \\
\text { dengan menunjuk orang yang } \\
\text { mengawasi pelaksanaan } \\
\text { informed consent }\end{array}$ & \\
\end{tabular}


\begin{tabular}{llll}
\hline 4 & $\begin{array}{l}\text { Merevisi } \quad \text { Form informed } \\
\text { consent, }\end{array}$ SK dan SPO & 13 \\
penyampaian informasi medis
\end{tabular}

Berdasarkan hasil observasi, ditemukan bahwa lebih dari setengah pasien di rumah sakit $\mathrm{X}$ membutuhkan bantuan dalam penjelasan lebih terkait informed consent karena health literacy yang dimiliki pasien rawat inap rendah. Sehingga dapat disimpulkan dari data tingkat lulusan pasien di RSU $X$ yang memiliki tingkat pendidikan SMP kebawah memerlukan alat dalam membantu pasien mengerti, meningkatkan retensi daya ingat pasien terkait informasi kesehatan yang diberikan oleh tenaga medis. Selain itu, untuk menentukan alat yang lebih berguna dapat disimpulkan dari kenyataan bahwa kemampuan baca pasien yang biasa, kesenangan membaca yang rata rata, frekuensi membaca yang ratarata dan jumlah jam yang dihabiskan untuk membaca yang sedikit, diperlukan media yang tidak memunculkan kata-kata yang banyak dan kompleks. Seperti poster, video, audio, demonstrasi, model, diagram, ataupun media pembelajaran lain yang sedikit mengandalkan kemampuan membaca pasien. Salah satu media yang membantu dalam pemahaman pasien dalam bentuk visual adalah photonovela.

Photonovela dapat membantu dalam menyampaikan instruksi atau pemberian informasi secara lisan ${ }^{8}$. Instruksi lisan harus diperkuat dengan bahan ajar cetak yang mudah dibaca secara visual, termasuk model dan ilustrasi. Media ini tidak menggantikan interaksi pribadi; mereka hanya dapat membantu memfasilitasi proses interaktif antara pasien dan tenaga medis, sehingga kehadiran alat bantu visual merupakan elemen penting dari pengajaran dan pemberian informasi antara pasien dan tenaga medis dalam pemberian informed consent tindakan tertentu. ${ }^{9}$

Pasien pada dasarnya tidak mengerti dan tidak mempunyai pengetahuan seputar informed consent yang dilakukan tenaga medis padanya. Tetapi responden pasien menyatakan dan mengakui bahwa pelaksanaan informed consent sangat penting baik bagi pasien itu sendiri dan rumah sakit pada umumnya. Hal ini mengindikasikan diperlukan pembelajaran / edukasi pada pasien terkait informed consent melalui media media informasi yang dapat diberikan di rumah sakit. ${ }^{10}$

Tenaga medis di RSU X yang melakukan tindakan medis, di dalam diri masing-masing memiliki pemahaman akan pentingnya pemberian informed consent pada pasien. Dengan dasar lama kerja di rumah sakit yang relatif baru maka, diperlukan suatu penekanan budaya kerja yang mengedepankan pentingnya pemberian informed consent dalam setiap tindakan kedokteran yang dilakukan. Selain itu, proses pendelegasian semaksimal mungkin haruslah diminimalisir untuk lebih memaksimalkan pelayanan terutama proses pemberian informed consent. Pembuatan Standard Operasional Prosedur dalam hal ini akan sangat membantu dalam proses pengaturan pelaksanaan pemberian informed consent.

Proses pelaksanaan informed consent yang ditujukan pada 50 pasien di rawat inap RSU X berjalan dibawah ekspektasi. Dari 9 elemen informed consent hanya 2 elemen yang memiliki data yang baik karena pasien dapat menjawab dengan baik. Untuk 7 elemen lain memiliki rekap nilai yang tidak baik. Hal ini mengindikasikan bahwa informasi yang diberikan para tenaga medis terhadap 
pemahaman dan retensi pemahaman informasi informed consent sangat tidak baik. Dengan keadaan seperti demikian, pemberian papan pengingat atau poster maupun guidebook penting diletakan pada tempat yang mudah dijangkau dan terlihat untuk membantu setiap pasien.

Jika ditelaah kembali terhadap evaluasi pelaksanaan informed consent oleh tenaga medis dan dibandingkan dengan evaluasi oleh pasien terhadap elemen-elemen informed consent yang sama, terlihat perbandingan antara proporsi yang dilakukan oleh tenaga medis dalam setiap element informed consent dan proporsi dampak melalui penilaian terhadap retensi dan pemahaman pasien. Selain itu dapat disimpulkan dalam memberikan informasi pelaksanaan pemberian informed consent dalam setiap elemen belum seluruhnya baik. Beberapa hal yang harus ditingkatkan adalah penjelasan tentang resiko, tata cara atau prosedur, komplikasi dan alternatif tindakan, dikarenakan proses yang kurang dilaksanakan oleh tenaga medis dengan dampak yang minimal pada pasien. Dalam berjalananya proses pelaksanaan penjelasan informed consent sepatutnya rumah sakit menunjuk petugas yang bertugas dalam mengontrol, monitoring dan evaluasi pelaksanaan informed consent tenaga medis dan pemahaman pasien atas penjelasan informasi medis. Melakukan pelatihan / workshop secara berkala perlu dipertimbangkan dalam meningkatkan kemampuan tenaga medis dalam melaksanakan informed consent.

Hasil evaluasi penjelasan informed consent secara keseluruhan baik sesuai data yang diisikan oleh pasien. Tetapi beberapa permasalahan esensial perlu diperbaiki dengan lanjut, seperti masih ditemukannya pasien yang mengaku tidak diberikan kesempatan untuk bertanya, konfirmasi tingkat pemahaman yang masih ditemukan pada sebagian besar pasien dan proses permintaan tanda tangan kepada pasien yang dilakukan setelah tindakan. Diperlukan suatu pengawas dan evaluator terhadap pelaksanaan tindakan informed consent pada pasien untuk meningkatkan kualitas pelayanan dan patient safety, mengingat kualitas pemberian pelayanan informed consent berpengaruh terhadap kepuasan pasien di suatu rumah sakit ${ }^{11}$.

Hasil penentuan alternatif solusi, manajemen perlu membuat media berupa photonovela untuk membantu perawat lebih mudah dalam memahami mengenai informasi medis dan teknik menjelaskannya pada pasien, dan perlu membuat handbook dengan sasaran tenaga medis untuk memberikan keterangan dan panduan dalam melakukan pemberian informed consent.

Sehingga terjadi kesinambungan antara upaya perawat untuk menjelaskan informasi medis dan upaya pada pasien untuk lebih mengerti terhadap materi atau informasi yang diberikan. Penentuan poster dengan menggunakan jenis photonovela dipilih berdasarkan tingkat efektifitas dalam memudahkan rumah sakit dalam memberikan penjelasan kepada pasien tanpa kehadiran tenaga medis tersebut $^{12}$.

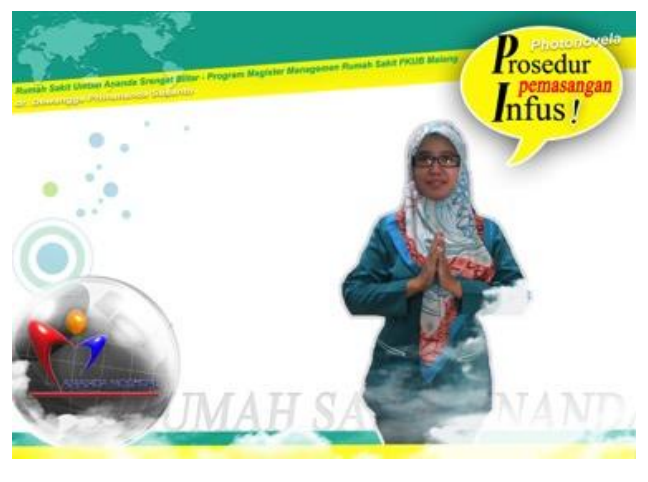



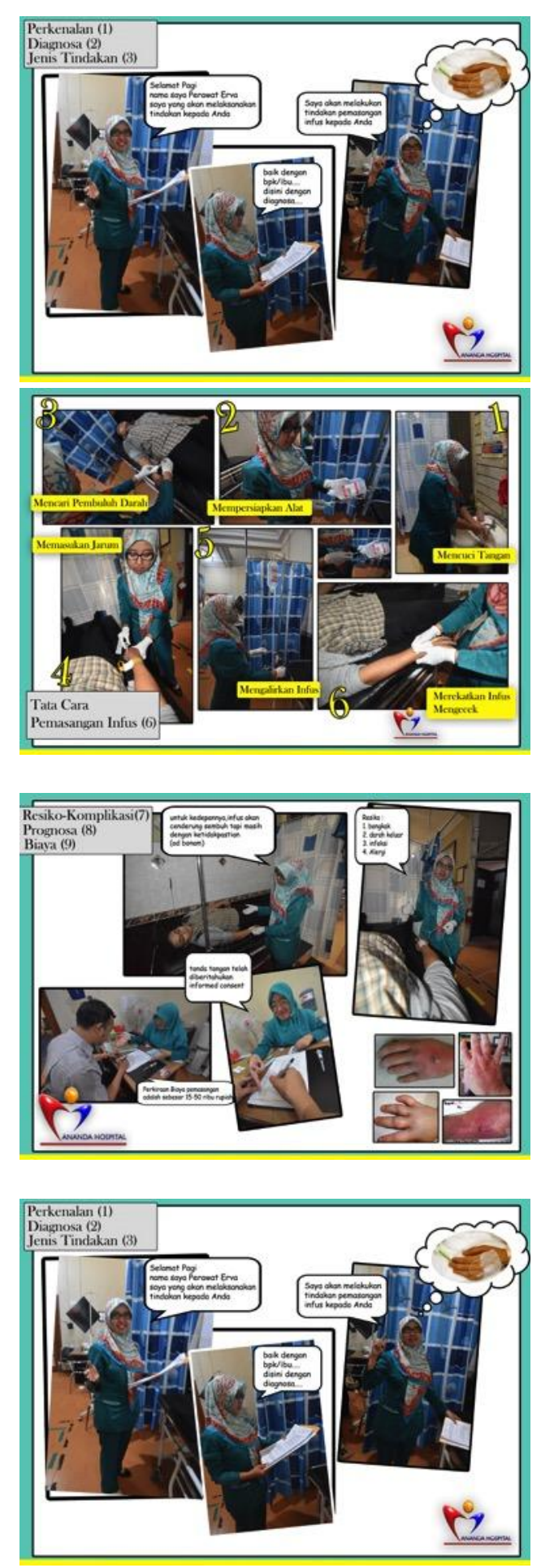

Gambar 1. Model Photonovela

Gambar 1. Tampilan Photonovela

\section{KESIMPULAN}

Hasil penelitian di RS X selama 2 bulan ditemukan bahwa permasalahan informed consent pasien dari unit rawat inap adalah pasien tidak mengerti tentang tata cara, tujuan, alternatif, resiko komplikasi, prognosa, dan perkiraan biaya tindakan yang dilakukan di unit rawat inap RS X.

Sedangkan rata-rata tenaga medis hanya mampu memberikan 5 keterangan mengenai informed consent dan benar rata-rata 4 elemen dari 9 elemen informed consent yang telah diatur dalam peraturan perundang-undangan. Hasil Focus Group Disscusion (FGD) dengan semua kepala ruangan di $\mathrm{RS} \mathrm{X}$ dan jajaran direksi menyimpulkan peramasalahan yang menjadi fokus penyelesaian adalah penyampaian informasi medis yang diberikan tenaga kesehatan tidak lengkap dan tidak dimengerti dengan baik oleh pasien. Alternatif solusi yang didapatkan berdasarkan metode pemilihan McNamara adalah pembuatan Handbook pedoman pemberian informed consent dengan pembuatan photonovela terkait penjelasan informasi medis untuk edukasi pasien serta meningkatkan pemahaman pasien terkait informed consent tindakan di RSU X.

\section{DAFTAR PUSTAKA}

1. Aiken, Sermeus LH, Heede WVd, Sloane K, Busse DM, McKee R, et al. Patient safety, satisfaction, and quality of hospital care: cross sectional surveys of nurses and patients in 12 countries in Europe and the United States. BMJ. 2012;344.

2. Samino S. Analisis Pelaksanaan Informed Consent. Jurnal Kesehatan. 2016;5(1).

3. Aisyah S, Kristiyono E. Faktor-faktor yang Menyebabkan Ketidaklengkapan Pengisian Lembar Informed Consent Tindakan Bedah Mata di RS. Mata "Dr. YAP" Yogyakarta: Universitas Gadjah Mada; 2013. 
4. Bose TK. Application of Fishbone Analysis for Evaluating Supply Chain and Business Process-A Case Study on the St James Hospital. International Journal of Managing Value and Supply Chains (IJMVSC). 2012;3(2):17-24.

5. AHEC. you can't tell by lookng! Assessing a patient's ability yo read \& understand health information. The ohio state university collage of medicine Clear Health Communication Program 2011(OHIO).

6. Jeppesen KM, Coyle JD, Miser WF. Screening questions to predict limited health literacy: a cross-sectional study of patients with diabetes mellitus. The Annals of Family Medicine. 2009;7(1):24-31.

7. No PMKRI. 290/Menkes. Per/III tahun. 2008.

8. Rahayu A, Murniati NAN, Farikhah I, editors. Kajian Pengembangan Media Pembelajaran IPA Menggunakan Fotonovela Berbasis Pendidikan Karakter. lpf2013; 2013.

9. Shekelle PG, Wachter RM, Pronovost PJ, Schoelles K, McDonald KM, Dy SM, et al. Making health care safer II: an updated critical analysis of the evidence for patient safety practices. Evidence report/technology assessment. 2013(211):1.

10. Graham S, John Brookey. Do Patients Understand? The Permanente Journal Summer 2008. 2008 Volume 12 No. 3.(California ).

11. Sari DP. Hubungan antara pemberian informed consent sebelum tindakan operasi dengan kepuasan pasien di rsud dr. moewardi. Jurnal infokes apikes citra medika surakarta. 2016;6(2).
12. Hinojosa MS, Hinojosa R, Nelson DA, Delgado A, Witzack B, Gonzalez $\mathrm{M}$, et al. Salud de la mujer: using fotonovelas to increase health literacy among Latinas. Progress in community health partnerships: research, education, and action. 2010;4(1):25-30. 